УДК 378.4:314.151.3-054.73-057.875-044.332

\title{
ЮРІЙ КРАЩЕНКО
}

ГАЛИНА СОРОКІНА

ЮЛІЯ БОЛОВАЦЬКА

Полтавський національний педагогічний університет імені В. Г. Короленка

\section{СОЦІОКУЛЬТУРНЕ ПРОЕКТУВАННЯ АДАПТАЦІЇ ВНУТРІШНЬО ПЕРЕМІЩЕНИХ СТУ ДЕНТІВ}

У статті розглядається досвід адаптації внутрішньо переміщених студентів через проектування соціокультурного простору міста як адаптивного середовища. Визначені особливості проблем адаптації внутрішньо переміщених студентів, механізм включення особистості у соціокультурне середовище. Запропонована проектна стратегія спрямована на розробку сценаріїв за участі студентів із числа внутрішньо переміщених осіб, що розвивають творчу уяву, фантазію, комунікативні навички, які формують соціальний оптимізм, світогляд, позитивні установки зі створення системи соціальних стосунків, заснованих на базових поняттях про систему людських цінностей.

Ключові слова: внутрішньо переміщені особи, студентська молодь, адаптація, середовище, соціокультурне проектування

Актуальність проблеми. Внаслідок подій, що тривають на Сході України, значна кількість людей змушена була залишити місця свого проживання та потребує різного роду підтримки від держави та приймаючих громад. За даними Департаменту соціального захисту населення Полтавської обласної державної адміністрації та відповідно до вимог постанови Кабінету Міністрів України від 01.10.2014 № 509 «Про облік внутрішньо переміщених осіб», станом на кінець 2016 року в Єдиній інформаційній базі внутрішньо переміщених осіб у Полтавській області зареєстровано 29496 осіб (19494 сімей) (Як живуть.., 2015).

На Полтавщині доволі позитивні показники забезпечення внутрішньо переміщених осіб соціальною допомогою. Рівень доступності освіти у вищих навчальних закладах у регіоні один із найвищих (понад 200 студентів із зони конфлікту перевелися на державну форму навчання в полтавські заклади вищої освіти) (Костиря, 2016). Проте залишаються невирішеними проблеми у ключових сферах - економічні, побутові, соціальні та психологічні. Разом із цим, все частіше піднімаються питання полегшення процесу соціально-психологічної адаптації та залучення внутрішньо переміщених студентів до повноцінної життєдіяльності в новому соціальному оточенні.

Згідно з аналітичною запискою Національного інституту стратегічних досліджень, особливої актуальності набувають питання формування соціокультурної політики. Враховуючи гуманітарні наслідки останніх подій, окрему увагу треба приділити питанням соціокультурної реінтеграції переселенців та зміцненню національної злагоди. Необхідно подбати про започаткування історико-культурних та просвітницьких проектів, спрямованих на формування громадянської позиції (Валевський, 2016). Отже, актуальним наразі стає вироблення основ нової стратегії, яка була б спрямована на побудову стабільного консолідованого суспільства та, поряд з цим, спиралася на традиційні цінності українського народу.

Метою статті $\epsilon$ представлення результатів соціокультурного проектування адаптації внутрішньо переміщених студентів.

Молодь - специфічна соціально-демографічна група суспільства, яка за своїм складом $є$ дуже неоднорідною, має внутрішню диференціацію, визначається особливостями діяльності, способом життя, динамічністю та інноваційним потенціалом (Психологічні особливості..., 2013). Особливої уваги в цьому аспекті потребує студентство.

Наразі ситуація внутрішньої еміграції містить у собі низку чинників, різнорідних як за масштабами, та і за змістом, що ушкоджують нервово-психічне функціонування молоді, зокрема студентства, які змушені повністю змінювати свій звичний спосіб життя, оточення, систему навчання тощо, адже переведення до нового навчального закладу в більшості випадків пов'язане зі стресом, страхом перед змінами, новим колективом та новим місцем тощо.

Період навчання у вищому навчальному закладі припадає на вік 17-23 роки. Це час найбільш активного розвитку моральних та естетичних почуттів, становлення і стабілізації характеру i, що особливо важливо, - оволодіння повним комплексом соціальних ролей дорослої людини, соціально-професійних, громадянських та ін. Із цим періодом також пов'язаний початок «економічної» активності, під якою 
демографи розуміють включення людини в самостійну продуктивну діяльність, створення власної сім'ї (Психологічні особливост і..., 2013, с. 17).

За цих умов необхідне формування нового типу комунікаційних форм, засобів, структур, процесів, створення нового середовища соціальної взаємодії. Це зумовлює проблеми щодо функціонування та розвитку нових типів культурних платформ, їхньої подальшої інтеграції до системи соціальних комунікацій суспільства.

Узагальнюючи дані українських моніторингових груп, які дають певну картину загальних проблем адаптації внутрішньо переміщених студентів, на перших позиціях перебувають, безумовно, соціальноекономічні, вирішення яких сформує позитивний мотив і до участі в суспільно-політичному житті міста (Аналітичний звіт...., 2015; Зінченко, 2015).. Крім того, існують психологічні проблеми, пов'язані 3 руйнуванням колишнього звичного способу життя, раптовим розривом соціальних зв'язків, невизначеністю свого майбутнього, культурними відмінностями нового середовища, занепокоєнням, відсутністю бачення особистих і професійних перспектив, які пригнічують студентів-переселенців однаковою мірою як проблеми матеріального характеру (Коробка \& Павлюк, 2015; Міхеєва \& Середа, 2015; Надгара, 2015).

За результатами наших опитувань, студенти-переселенці серед труднощів, із якими вони стикаються, виявлені наступні: апатія - 56\%; бар'єри, дискомфорт у спілкуванні з оточуючими, відповідно - вузьке коло спілкування - 38\%; відчуженість нового колективу, групи, тощо - 39\%; складнощі соціальної адаптації на новому місці - 45\%; соматичні прояви психічних станів - 69\%; внутрішній страх перед новим, самоневизначеність та невпевненість, зосередженість на собі - 53\%; страх виявити свої творчості здібності та неможливість їх розвитку й реалізації - 41\%. Крім того, дослідження показало, що переміщені студенти не бажають відкрито говорити про свої проблеми. Багатьом із них не комфортно, або навіть соромно звертатися за допомогою, навіть якщо це їм необхідно. Переважна більшість студентів мають посттравматичний синдром, викликаний постійною тривогою за своїх рідних та близьких.

Наявність соціокультурного середовища - необхідна та обов'язкова умова соціалізації особистості. Саме соціокультурне середовище формує певні очікування щодо поведінки особистості [2, С. 109]. Вище зазначене означає, що студенти з числа внутрішньо переміщених осіб вимагають залучення до соціокультурного простору міста як адаптивного середовища.

Під соціокультурним середовищем більшість дослідників (М. Гагарін, О. Малишев, В. Ремізов, Н. Хілько та ін.) розуміють складну структура суспільних, матеріальних і духовних чинників, через які реалізується діяльність студентів; систему ключових факторів, що визначають освіту і розвиток, які впливають на освітні процеси; природне середовище; засоби масової інформації; випадкові події. Соціокультурне середовище $\epsilon$ цілісним, автономним і відкритим культурно-освітнім простором із пріоритетом гуманістично-моральних цінностей.

Як засвідчує практика та аналіз наукової літератури, найбільш невимушено й органічно формується і проявляється соціальна активність студентів у культурно-просвітницькій сфері. 3 одного боку, молодь має змогу провести вільний час, відпочити, діяти за інтересами, а з другого - організатори соціального виховання мають змогу змоделювати таку культурно-просвітницьку сферу, в якій кожна молода людина матиме змогу не лише задовольняти свої інтереси і потреби, але й бути активним учасником у створенні і реалізації соціальних проектів, які є важливим фактором формування соціальної активності (Бушуєв \& Морозов, 2014; Каменец, Урмина \& Селезнева, 2011; Шабанова, 2015). Таке розуміння і використання факторів впливу на особистість робить дозвілля специфічною формою самовираження, коли вільний час перетворюється на засіб активного розвитку молоді.

Вагомий внесок у сучасні дослідження розвитку означеної проблеми зробили В. Білоконь, О. Бойко, Ю. Боловацька, В. Бочелюк, А. Жарков, Ю. Красильников, Н. Максимовська, Г. Михайлів, I. Петрова, М. Рутинський, О.Сасихов, Ю.Стрільцов, Н. Цимбалюк та ін., у яких аналізуються форми реалізації багатофункціональних проектів, розробляються моделі культурно-просвітницької діяльності, принципи функціонально-планувальної організації закладів дозвілля, визначається їх освітній потенціал та педагогічні умови функціонування тощо. Отже, наразі зростає увага до соціальних проектів.

Поділяємо думку І. Петрової щодо причин зростаючого попиту на соціокультурні проекти i погоджуємось із її визначенням: «...проект - це реакція соціокультурної сфери на зміни зовнішнього середовища» (Петрова, 2007, с. 12).

Соціокультурне проектування будемо розглядати як засіб адаптації внутрішньо переміщених студентів шляхом формування в особистості індивідуально та соціально значущих якостей, які сприяють діяльнісному, творчому засвоєнню й розвиткові культурних цінностей, духовному збагаченню, гармонізації особистості з навколишнім середовищем.

При цьому, соціокультурне середовище охарактеризоване як сукупність соціальних, культурних, а також спеціально організованих психолого-педагогічних умов, у результаті взаємодії яких відбувається становлення особистості студента та його адаптація до умов життєдіяльності.

Аналіз наукових позицій дозволив зробити висновок про те, що механізм включення особистості у соціокультурне середовище $є$ своєрідним джерелом іiї духовного потенціалу. Всі компоненти середовища перебувають у постійному взаємозв'язку, забезпечуючи цілісність культури як системи і створюючи основу для взаємозв'язку джерел формування духовного потенціалу соціокультурної сфери особистості, серед яких 
найістотнішими є саморозвиток, засоби масової інформації та спілкування. Цим і визначаються особливості проектування соціокультурної діяльності для адаптації внутрішньо переміщених студентів.

Багатогранність факторів соціокультурного середовища сприяє формуванню у молоді таких якостей, як інтелектуальна мобільність, готовність засвоювати нову інформацію, рівень освіченості, культури і почуттів, об’єктивне і наукове пізнання світу. Фактори культурної сфери допомагають молодій людині продуктивно взаємодіяти з іншими сферами життєдіяльності і з іншими соціальними інституціями.

Погоджуємося 3 думкою В. Казіміренко про те, що помітним фактором впливу соціокультурного середовища на формування соціальної активності студентів з числа внутрішньо переміщених осіб $\epsilon$ інформаційне оточення. Молода людина потребує постійного розширення інформаційної сфери, оскільки вона повинна орієнтуватися у широкому інформаційному полі. Формування інформаційної культури молоді $\epsilon$ обов'язковою умовою розвитку особистості загалом. Поінформованість молоді - не «нав'язування» певних моделей поведінки, уподобань, політичних поглядів, це й підтримка народних традицій, це формування світоглядної цілісності, це збереження мовної культури, сприйняття державної атрибутики, позитивне ставлення до громадянства, прояв етнічної толерантності, терпимості. Безперечно, в кожній із означених сфер життєдіяльності студентської молоді домінують ті чи інші фактори. Так, у культурно-просвітницькій чи фізкультурно-оздоровчій сферах особливо значущим є фактор спілкування, який допомагає формуванню у молоді навичок мовленнєвої взаємодії, прояву ставлення до інших людей (Казіміренко, 2004, с. 77).

Значення соціокультурного середовища у становленні соціально активної особистості не є єдиною умовою успішної адаптації внутрішньо переміщених студентів, але, водночас, органічне й адекватне конкретній сфері використання соціально-педагогічних факторів - все це створює духовно-моральну атмосферу в молодіжному мікросоціумі. Особливо ефективні проекти за участі студентського самоврядування.

У межах наукової теми «Адаптація внутрішньо переміщених осіб до університетського середовища засобами студентського самоврядування» реалізується соціальний проект «Літературно-музичне кафе», цільовою аудиторією якого стали студенти-переселенці із Донецької і Луганської областей, вимушено переміщені особи, яким бракує знань про культурні особливості м. Полтава та які почуваються чужими, а також мешканці Полтави, що безпосередньо спілкуються 3 вимушено переміщеними особами та потребують розуміння і прийняття ситуації, що склалася.

Проектна стратегія спрямована на розробку сценаріїв за участі студентів із числа внутрішньо переміщених осіб, що розвивають творчу уяву, фантазію, комунікативні навички, які формують соціальний оптимізм, світогляд, позитивні установки зі створення системи соціальних стосунків, заснованих на базових поняттях про систему людських цінностей.

Метою проекту визначено: інтегрувати внутрішньо переміщених студентів у культурне середовище м. Полтави та сприяти їхній адаптації.

Завданнями проекту стало:

Об'єднати зусилля державних і недержавних організацій, які працюють у сфері культури, освіти та допомоги вимушено переміщеним студентам для повноцінної інтеграції у соціокультурний простір міста.

Розробити систему соціокультурної адаптації студентської молоді із числа внутрішньо переміщених осіб шляхом культурних і просвітницьких заходів, спрямовану на формування української ідентичності.

На базі існуючих закладів створити простір для самореалізації та самозайнятості внутрішньо переміщених студентів (творчі майстерні, студії, центри тощо), самоідентифікації та налагодження соціокультурних зв'язків між внутрішньо переміщеними студентами та громадами м. Полтава.

Напрямки проекту «Літературно-музичне кафе»:

1. Культурно-історична спадщина (або історичне середовище проживання людини, міра ії освоєння і попиту);

2. Художнє середовище проживання людини, що забезпечує відповідні форми їі активності з освоєння і розвитку предметів та цінностей художньої культури, якість мистецького життя;

3. Соціально-психологічне середовище проживання (характер міжособистісних відносин найближчого оточення, форм і способів спільної життєдіяльності людей - їх виробничі і сімейні, формальні і неформальні зв'язки і відносини);

4. Духовно-моральне місце життєдіяльності (як у формі громадської моралі, так i на інтерсуб'єктивному рівні - як внутрішньо особистісний зміст духовно-моральних цінностей, норм, ідеалів, смислів людського життя).

Проектуючи соціально-виховні процеси, важливим є визнання того, що соціальна активність молоді проявляється як досить грунтовна життєва установка особистості, котра усвідомлює, що все необхідне вона отримує від суспільства, завдячуючи своїй соціально значущій діяльності, причому результатами цієї діяльності вона обмінюється з іншими людьми.

Повертаючись до питання суб'єктності молоді у соціально-виховних процесах і проявах соціальної активності, слід наголосити на тому, що соціальна активність особистості (з притаманними ознаками лише кожній конкретній особистості) проявляється у різних сферах її соціального життя.

Літературно-музично кафе - явище для нашого суспільства ще досить нове. Про це свідчить і скромна кількість пропозицій. Літературно-музичне кафе - заклад, який поєднує в собі безпосередньо кафе (ресторан, бар) з книжковим та/або музичним магазином, бібліотекою, де також передбачається живе спілкування з виконавцями літературних та музичних творів. 
Простір літературного кафе - середовище, де мистецтво втілюється у життя самим процесом експонування, це пошук зворотного зв'язку від оточення до людей, які в ньому знаходяться і сприймають запропоноване мистецтво.

Головна особливість такого кафе полягає в тому, щоб розважати своїх відвідувачів 3 високою унікальністю, для того, щоб люди знову і знову хотіли прийти і побачити новий захід - живу музику як маловідомих груп, так і іменитих виконавців; поетичний вечір або гумористичний стендап-жанр. У такий спосіб тематичний заклад (кіно-, бібліотечний, артистичний) стає вже не стільки об'єктом харчування, скільки клубом для однодумців.

У межах цієї проектної стратегії були використані різні форми роботи, наприклад, ігрові та театралізовані дійства, в яких брали участь студенти-переселенці та студенти з органів студентського самоврядування університету, завдяки зусиллям яких організовувалися заходи.

Зокрема, студенти-переселенці взяли участь у театралізованих виставах до Дня Всіх Святих, що передбачало різні за характером та настроєм ролі. Можливість перевтілюватися як в позитивних, так і в негативних персонажів покликана допомогти студентам краще адаптуватися в суспільстві, звикати до різних емоцій і легше переживати можливі стреси, спричинені життєвими реаліями. У цьому спільному процесі реалізувався інтелектуально-творчий потенціал у різних напрямах: у підготовці сценаріїв, режисурі, в акторській майстерності, в підборі музичних творів, ігровій розвиваючій діяльності, в художньому оформленні закладу тощо.

Цікавою для студентів-переселенців стала вулична акція «Горнятко енергоефективності», що була приуроченої Міжнарожному дню енергозбереження та вторинної переробки. За кожні 3 кг відсортованої вторсировини (макулатура, ПЕТ-пляшки) ПП «Львівська кав'ярня» пригощала горнятком гарячої кави, а літературно-музичне кафе підготувало лекцію про те, як, здаючи сміття на переробку, можна оплачувати комунальні послуги та як ефективно економити енергію вдома, а також майстер-класи 3 виготовлення хендмею зі вторсировини. Такі заходи спрямовані на формування екологічного світогляду молоді, залучення їх до економічних проблем держави та їх вирішення на регіональному та індивідуальному рівні.

Активно залучилися студенти, в тому числі й до акції з нагоди Дня студента, яка передбачала участь у конкурсі креативних фотографій академічних груп. Переможців чекала чайна церемонія. Головний результат таких проектів полягає у формуванні креативної, соціально активної особистості, здатної створювати соціокультурний простір.

Наступна проектна стратегія полягала у створенні умов для формування особистісних якостей, необхідних для самоствердження та розвитку вольових навичок при взаємодії із соціумом. Поширені в суспільстві тенденції до конформізму, пасивності вимагають нового соціального досвіду для надбання якостей соціально активних лідерів, відповідальних й ініціативних професіоналів. Студенти, які беруть участь у подібних проектних стратегіях можуть, передусім, позиціонувати себе, як досвідчені організатори, ініціатори громадської активності, які стимулюють формування та прояв ціннісних життєвих орієнтацій. Дана проектна діяльність студентів здійснюється на базі волонтерської практики у різноманітних благодійних акціях, громадських заходах тощо за принципом: «допомагаєш самореалізовуватись іншим самореалізовуєшся сам».

Наприклад, студенти із числа внутрішньо переміщених осіб, жваво залучилися до літературника, що відбувся до Дня української писемності. Літературник «Поезія за чашкою кави». За чашкою запашної кави слухали твори класиків та сучасників української літератури (вірші Тараса Шевченка, Івана Франка, Володимира Сосюри, Грицька Чубая, Сергія Жадана, Юрія Іздрика, Зази Пауалішвілі, Михайла Жаржайла), що прозвучали не лише у виконанні учасників незалежного мистецького об'єднання «Magnum Opus», а й талановитих полтавців та гостей заходу.

Багато студентів-переселенців відвідали презентацію книги «Донбас - арена війни» видання якої було здійснено в рамках інформаційної кампанії «Почути - Зрозуміти - Порозумітися», що проводилася у межах проекту «Сприяння плюралізму та діалогу в українському суспільстві». У презентації брали участь автори збірника - переселенці, викладачі та студенти полтавських вишів.

У межах круглого столу «Захист прав людини - гарантія розвитку громадянського суспільства», проводилися консультації «Захист внутрішньо переміщених осіб» для учасників заходу - переселенців. Поряд з цим, у літературному кафе проводилися навчально-тренінгові курси для студентської молоді віком від 18 до 24 років, у т.ч. вимушених переселенців. Метою курсів було сприяння розвитку творчого потенціалу студентської молоді та підвищення рівня їх психологічної стабільності.

У межах зазначеної діяльності для студентів-переселенців також проводилися тренінги особистісного зростання, комунікативного розвитку, організаційних навичок, упевненості у собі та ін. Таким чином, проектується певний соціальний простір, сприятливий, у першу чергу, для формування молодіжного лідерства з числа студентства.

Отже, у пропонованому проекті реалізується унікальна можливість розвитку та адаптації внутрішньо переміщених студентів: а) індивідуальних, б) групових, в) колективних, г) допрофесійних.

Поряд із іншим, реалізація проекту на місцевому рівні сприяла інтеграції внутрішньо переміщених студентів у культурне середовище через:

- підтримку молодіжних художніх ініціатив, що представляють художнє бачення культурних, наукових і соціальних проблем; 
- розширення кола кураторів сучасного мистецтва через надання їм можливостей освіти в поєднанні 3 практичним досвідом;

- пошук нових імен і талантів в сфері сучасного мистецтва;

- збільшення кількості залучених студентів у культурно-дозвіллєву сферу.

Саме через організацію роботи арт-майстерень, публічних майстер-класів, фотовиставок, виставок хендмею, проведення DJ-set, лекторіумів, спілкуванні 3 однолітками, впровадження інтерактивних механізмів розширення творчих та економічних можливостей, постійній участі у культурних, мистецьких та екологічних заходах міста, у кав'ярні створюються ефективні умови щодо подолання непередбачуваних негативних соціальних наслідків, сприяння налагодженню діалогу та порозуміння внутрішньо переміщених студентів з місцевою спільнотою.

\section{Список використаних джерел}

Аналітичний звіт за результатами опитування, ВПО та приймаюча громада [Електронний ресурс]. Підготовлено Свропейською дослідницькою асоціацією (ERA). - 2015. - Режим доступу: https://cloud.mail.ru/public/3mSh/81srznM6k/ERA_InMind_ВПО\%20та\%20прий маюча\%20громада_Листопад\%202015_Ukr.pdf

Безпалько, О.В. (2009). Сочуільна педагогіка: схеми, таблиці, коментарі: навч. посіб. [для студ. вищ. навч. закл.] Київ. : Центр учбової літератури

Бушуев, С. Д., Морозов, В.В. (2014). Динамическое лидерство в управлении проектами. Киев: Украинская ассоциация управления проектами.

Валевський, О.Л. (2018) Актуальні проблеми державної підтримки інновацій у культурній політиці : [Аналітична записка] Київ : Національний інститут стратегічних досліджень. - № 11. - Серія «Гуманітарний розвиток». - Електронний ресурс : Режим доступу : http://www.niss.gov.ua/articles/1651/

Зінченко, О.С. (2015). Теоретичні засади дослідження соціально-психологічної адаптації внутрішньо переміщених осіб Актуальні проблеми соціологї, психологї, педагогіки, 4, 47-53.

Казміренко, В.П. (2004). Програма дослідження психолого-соціальних чинників адаптації молодої людини до навчання у ВНЗ та майбутньої професії. Практична психологія та соціальна робота., 6, 76-78.

Каменец, А.В., Урмина, И. А., Селезнева, Е. Н. (2011). Моделирование ситуаций социиокультурного взаимодействия как пространство самореализации молодежи. Москва: Изд-во РГСУ.

Коробка, І., Павлюк, В. (2015). Організаційно-правові засади соціального захисту переселенців (внутрішньо переміщених осіб) як основа реалізації соціальної політики держави, механізми формування соціальноефективної державної економічної політики в умовах демократизації суспільства. Skhid, 4, 136.

Костиря, О. (2016). Реалії життя внутрішньо переміщених осіб у Полтавській області. Трибуна : незалежна преса Полтави [Електронний ресурс] : Режим доступу : https://ribuna.pl.ua/news/realiyi-zhittya-vnutrishnoperemishhenih-osib-u-poltavski-oblasti/

Міхеєва, О., Серепда, В. (2015). Сучасні українські внутрішньо переміщені особи: основні причини, стратегії переселення та проблеми адаптації. Стратегї трансформаціі $і$ превенції прикордонних конфліктів в Україні : Збірка аналітичних матеріалів. - Львів : Галицька видавнича спілка.

Надгара, В. І. (2015). Проблеми вимушеної внутрішньої міграції населення в контексті концепції «суспільства ризику». Український соиіум,1, 134-141.

Петрова, І. В. (2007). Проектування в сочіально-культурній сфері: навчальний посібник. Київ : Вид-во КНУКіМ. Психологічні особливості студентського віку. На допомогу кураторам. (2013). Вип. 3. Яворовська, Л. М., Камишнікова, Р. Ф., Поліванова, О. С., Яновська, С. Г., Куделко, С.М. (Укл.). Х. : ХНУ імені В. Н. Каразіна.

Шабанова, М.А. (2015). Социальная адаптация в контексте свободы. Социологические исследования, 9, 81-88.

Як живуть переселенці у Полтавській області: цицри та факти. - Електронний ресурс : Режим доступу : http://www.adm-pl.gov.ua/news/yak-zhivut-pereselenci-u-poltavskiy-oblasti-cifri-ta-fakti

\section{References}

Analitychnyi zvit za rezultatamy opytuvannia, VPO ta pryimaiucha hromada [Elektronnyi resurs]. Pidhotovleno Yevropeiskoiu doslidnytskoiu asotsiatsiieiu (ERA). $-2015 . \quad$ Rezhym dostupu: https://cloud.mail.ru/public/3mSh/81srznM6k/ERA_InMind_VPO\%20ta\%20pryi maiucha\%20hromada_Lystopad\%202015_Ukr.pdf

Bezpalko, O.V. (2009). Sotsialna pedahohika: skhemy, tablytsi, komentari: navch. posib. [dlia stud. vyshch. navch. zakl.] Kyiv. : Tsentr uchbovoi literatury

Bushuev, S. D., Morozov, V.V. (2014). Dynamycheskoe lyderstvo v upravlenyy proektamy. Kyev: Ukraynskaia assotsyatsyia upravlenyia proektamy.

Valevskyi, O.L. (2018) Aktualni problemy derzhavnoi pidtrymky innovatsii u kulturnii politytsi : [Analitychna zapyska] Kyiv : Natsionalnyi instytut stratehichnykh doslidzhen. - № 11. - Seriia «Humanitarnyi rozvytok». - Elektronnyi resurs : Rezhym dostupu : http://www.niss.gov.ua/articles/1651/

Zinchenko, O. S. (2015). Teoretychni zasady doslidzhennia sotsialno-psykholohichnoi adaptatsii vnutrishno peremishchenykh osib. Aktualni problemy sotsiolohii, psykholohii, pedahohiky, 4, 47-53.

Kazmirenko, V.P. (2004). Prohrama doslidzhennia psykholoho-sotsialnykh chynnykiv adaptatsii molodoi liudyny do navchannia u VNZ ta maibutnoi profesii. Praktychna psykholohiia ta sotsialna robota., 6, 76-78.

Kamenets, A. V., Urmyna, Y. A., Selezneva, E. N. (2011). Modelyrovanye sytuatsyi sotsyokulturnoho vzaymodeistvyia kak prostranstvo samorealyzatsyy molodezhy. Moskva: Yzd-vo RHSU. 
Korobka, I., Pavliuk, V. (2015). Orhanizatsiino-pravovi zasady sotsialnoho zakhystu pereselentsiv (vnutrishno peremishchenykh osib) yak osnova realizatsii sotsialnoi polityky derzhavy, mekhanizmy formuvannia sotsialnoefektyvnoi derzhavnoi ekonomichnoi polityky v umovakh demokratyzatsii suspilstva. Skhid, 4, 136.

Kostyria, O. (2016). Realii zhyttia vnutrishno peremishchenykh osib u Poltavskii oblasti. Trybuna : nezalezhna presa Poltavy [Elektronnyi resurs] : Rezhym dostupu : https://tribuna.pl.ua/news/realiyi-zhittya-vnutrishnoperemishhenih-osib-u-poltavski-oblasti/

Mikheieva, O., Serepda, V. (2015). Suchasni ukrainski vnutrishno peremishcheni osoby: osnovni prychyny, stratehii pereselennia ta problemy adaptatsii. Stratehii transformatsii i preventsii prykordonnykh konfliktiv v Ukraini : Zbirka analitychnykh materialiv. - Lviv : Halytska vydavnycha spilka.

Nadhara, V. I. (2015). Problemy vymushenoi vnutrishnoi mihratsii naselennia v konteksti kontseptsii «suspilstva ryzyku». Ukrainskyi sotsium,1, 134-141.

Petrova, I. V. (2007). Proektuvannia v sotsialno-kulturnii sferi : navchalnyi posibnyk. Kyiv : Vyd-vo KNUKiM.

Psykholohichni osoblyvosti studentskoho viku. Na dopomohu kuratoram. (2013). Vyp. 3. Yavorovska, L. M., Kamyshnikova, R. F., Polivanova, O. Ye., Yanovska, S. H., Kudelko, S.M. (Ukl.). Kh. : KhNU imeni V. N. Karazina.

Shabanova, M.A. (2015). Sotsyalnaia adaptatsyia v kontekste svobody. Sotsyolohycheskye yssledovanyia, 9, 81-88.

Yak zhyvut pereselentsi u Poltavskii oblasti: tsyfry ta fakty. - Elektronnyi resurs : Rezhym dostupu : http://www.admpl.gov.ua/news/yak-zhivut-pereselenci-u-poltavskiy-oblasti-cifri-ta-fakti

\section{KRASHCHENKO Y., SOROKINA H., BOLOVATSKA YU.}

Poltava V. G. Korolenko national pedagogical University, Ukraine

\section{SOCIO-CULTURAL PROJECTION OF THE ADAPTATION OF INTERNALLY DISPLACED STUDENTS}

The article examines the experience of adaption of internally displaced students by means of the projection of the city's socio-cultural space as an adaptive environment. The features of the adaptation problems of internally displaced students, the mechanism of inclusion of the individual in the socio-cultural environment are determined. The proposed project strategy is aimed at developing scenarios involving internally displaced students which will develop creative imagination, fantasy, communication skills and which form social optimism, world view, positive attitudes towards creating a system of social relationships based on basic concepts of the system of human values.

In addition, the implementation of the project at the local level has facilitated the integration of internally displaced students into the cultural environment through: support of youth artistic initiatives that represent an artistic vision of cultural, scientific and social problems; expansion of the circle of curators of contemporary art by providing them with educational opportunities in combination with practical experience; search for new names and talents in the field of contemporary art; increase in the number of students involved in the cultural and leisure sphere.

Key words: internally displaced persons, student youth, adaptation, environment, socio-cultural design

Стаття надійшла до редакції 22.09.2018 р.

УДК 373.2:37.015

ОЛЕНА ЛОБАЧ

Полтавський національний педагогічний університет імені В. Г. Короленка

\section{МЕТОДИ ТВОРЧОГО РОЗВИТКУ МОЛОДШИХ ШКОЛЯРІВ НА УРОКАХ МУЗИЧНОГО МИСТЕЦТВА}

У статті класифіковано методи творчого розвитку учнів початкової школи на уроках музичного мистецтва, яка включає п'ять груп методів (музично-творчі, перцептивно-творчі, інтерпретаційнотворчі, комунікативно-творчі, науково-творчі).

Ключові слова: урок музичного мистецтва, творчий розвиток, класифікація методів творчого розвитку (музично-творчі, перцептивно-творчі, інтерпретаційно-творчі, комунікативно-творчі, науково-творчі)

Постановка проблеми. Одним із пріоритетних завдань сучасної педагогіки $є$ творчий розвиток особистості, що обумовлено об'єктивними соціальними та культурними чинниками, природною креативністю дитини, домінуванням творчості в пізнанні та перетворенні світу, бо творчо й самостійно засвоєне людиною стає їі особистісним надбанням. У Державному стандарті початкової освіти, затвердженому постановою Кабінету Міністрів України від 21 лютого 2018 р. за № 87, зазначено: «Метою початкової освіти є всебічний розвиток дитини, іiї талантів, здібностей, компетентностей та наскрізних умінь ..., формування цінностей, розвиток самостійності, творчості та допитливості» (Про затвердження..., 2018). 